\title{
Nowoczesny homo ludens. Paryski hipodrom w korespondencji Henryka Sienkiewicza
}

Już pierwszy akapit paryskiego felietonu o wyścigach konnych nie pozostawia wątpliwości, iż jego autor znał jeszcze z Warszawy ten rodzaj rozrywki. Nie jest też wykluczone, że orientował się w aktualnej koincydencji czasowej: warszawskie wyścigi odbyły się w pierwszych dniach czerwca 1878 r., a te paryskie - 16 czerwca $^{1}$; rodzimy zaś czytelnik mógł o nich przeczytać w "Gazecie Polskiej” pod koniec tegoż miesiąca. Sienkiewicz nie ułatwia zatem sobie zadania: nie pisze o czymś, z czym jego odbiorca nie mógłby się zetknąć (np. o wystawie powszechnej); przeciwnie - podejmuje temat bieżący, „na czasie”. I jakkolwiek różnica między Paryżem a Warszawą była niezaprzeczalna, to jednak w tym kontekście - dość zrutynizowanej procedury sportowej i hazardowej - wielce nieoczywista.

$\mathrm{Z}$ tego, jak się wydaje, powodu od początku tej korespondencji wyraźny jest zamiar polegający na stworzeniu ujęcia niebanalnego, oryginalnego. Z pomocą - a może i z natchnieniem - przychodzi pisarzowi sama ekspozycja. To bowiem dzięki niej na paryskim hipodromie znajduje się nie tylko „wielki świat”, ale „cały świat” - „setki tysięcy cudzoziemców ze wszystkich

\footnotetext{
* Projekt został sfinansowany ze środków Narodowego Centrum Nauki przyznanych na podstawie decyzji numer DEC-2012/06/A/HS2/00252.

1 Warto zaznaczyć, iż faktograficzna kanwa - od daty wyścigu po wygraną angielskiego konia - felietonu Henryka Sienkiewicza jest wierna ówczesnej rzeczywistości [zob. M. Gomez, Histoire des courses de chevaux. Des orgines à nos jours, Paris 2008, s. 35].
} 
stron świata" [s. 98 $]^{2}$. Sytuacja jest więc bezprecedensowa: oto jednej i tej samej rozrywce oddają się ludzie różnych narodów i kręgów kulturowych ${ }^{3}$.

Fakt ten Sienkiewicz wykorzystuje w nader znamienny sposób. Już na wstępie deklaruje, że okoliczności, w jakich się znalazł, określić można mianem „prawdziwej wystawy antropologicznej” [s. 98]. Oznacza to, że owo niebywałe zainteresowanie sprawia, iż bariery czy różnice kulturowe stają się nieistotne, a tym, co można tu bezpośrednio obserwować, jest istota ludzka - człowiek ,jako taki".

Podobnym zadaniem, jak wiadomo, zajmowała się ówczesna antropologia. Pisarz niedawno obejrzał jej osiągnięcia prezentowane na wystawie i chociaż w osobnej korespondencji - z sierpnia 1878 r. - wypowie się o nich raczej z aprobatą, tu jednak pozwala sobie na ironiczny dystans. Naukowe instrumentarium okazuje się bowiem niepotrzebne, skoro każdy może tu być antropologiem. Jest tak dlatego, iż:

każdy, na koniec, mógłby zapomnieć, że znajduje się w Paryżu, a pomyśleć, że jakaś siła nieznana zamieszała nagle w mrowisku ludzkim jak w garnku lub że Lasek Buloński i Longchamps to dolina Jozafata, na której narody ziemi wyprawiły sobie, $\mathrm{w}$ wigilię sądu ostatecznego, majówkę.

Wszystko też było strojne, świąteczne i wesołe [s. 98].

Gromadzenie i badanie zbiorów zostaje tu implicite zdyskwalifikowane. „Prawdziwa” antropologia polega na obserwacji człowieka żywego i działającego; w tym przypadku - biorącego udział w rozrywce. Jej uczestnicy pozwalają bowiem dostrzec to, co poważne i zarazem głębokie, a co pozostaje zakryte pozorami „majówki”, beztroskiej zabawy, której tak namiętnie się oddają. Ogarniając gromadzących się na hipodromie ludzi, Sienkiewicz stwierdza:

Wszystko to biegło bawić się, patrzeć, zakładać, wygrywać, przegrywać i krzyczeć [s. 100].

Wszyscy zatem są bezpośrednio, głęboko zaangażowani w to, co polszczyzna określa mianem gry i zabawy. O tym, że terminy te nie są synonimami, przekonuje niniejszy tekst, który wydobywa i niuansuje rozmaite

\footnotetext{
${ }^{2}$ W ten sposób odsyłam do: H. Sienkiewicz, Listy z podróży i wycieczek, Warszawa 1950; cyfra $\mathrm{w}$ nawiasie oznacza stronę.

3 Nieoczywisty charakter wydarzenia dobrze ilustruje anegdota o perskim szachu: „który podczas pobytu w Anglii z podziękowaniem odrzucił propozycję przypatrywania się wyścigom konnym, uzasadniając odmowę tym, iż wie przecież, »że jeden koń biegnie szybciej od drugiego «" [J. Huizinga, Homo ludens. Zabawa jako źródło kultury, przeł. M. Kurecka, W. Wirpsza, Warszawa 1967, s. 78].
} 
aspekty takiej działalności. Narzędzi do ich opisu dostarcza - w sposób, jak się wydaje, najlepszy - koncepcja, jaką wyłożył Roger Caillois w pracy Gry i ludzie. Zachowania na hipodromie spełniają bowiem wszystkie sześć cech, które socjolog uważa za konstytutywne dla gier i zabaw [zob. G, s. 20] ${ }^{4}$. Sienkiewicz zauważa: (1) dobrowolny udział uczestników, (2) precyzyjne wyodrębnienie miejsca i czasu, (3) istnienie elementu niepewności, (4) bezproduktywny charakter i przemieszczanie własności w obrębie grających, (5) istnienie innych, odrębnych od rzeczywistych reguł oraz (6) fikcyjny status przedsięwzięcia. Wyznaczniki te są oczywiście formalne - i pozwalają jedynie na legitymizację interpretacyjnych instrumentów. Dalsze ich użycie zależy już od konkretnego modusu tejże aktywności.

\section{Mimikra}

Zasadniczy temat korespondencji - przebieg zawodów - w zasadzie nie pozwala na stworzenie odpowiedniej narracji. Sienkiewicz nie ukrywa zatem, że bardziej niż same wyścigi interesują go widzowie hipodromu. Przybywa na miejsce ponad trzy godziny przed główną gonitwą [por. s. 98 i s. 107], dzięki czemu jest w stanie prowadzić dokładne i wielorakie obserwacje. Jeszcze ważniejszy jest fakt, iż wykonywanie owego zadania dokonane zostanie z pozycji zewnętrznej. Sienkiewicz podkreśla, że jego przedsięwzięcie byłoby niemożliwe, gdyby nie zaprzyjaźniony dziennikarz, który pełni rolę przewodnika [por. s. 98-99]. W ten sposób - implicite - pisarz sobie samemu gwarantuje dystans i brak jakiejkolwiek oczywistości w oglądzie pojawiających się przed nim zjawisk ${ }^{5}$.

Zabieg ten posiada jeden zasadniczy cel. Owo zewnętrzne, czyli nieuprzedzone, nieuwarunkowane i „czyste" spojrzenie reportera jest najlepszą gwarancją właściwego ujęcia rzeczywistości. Ten rodzaj uwiarygodnienia był, jak się wydaje, niezbędny, ponieważ wynik oglądu nieustannie - a nawet: monotonnie - oscyluje wokół tego samego wniosku. Im bardziej wielorakie i odmienne są tu „obiekty”, tym wyraźniej rysuje się bowiem redukcyjna me-

\footnotetext{
4 W ten sposób odsyłam do: R. Caillois, Gry i ludzie, przeł. A. Tatarkiewicz, M. Żurowska, Warszawa 1997; cyfra w nawiasie oznacza stronę.

5 Jest to metoda ściśle literacka, którą określa się mianem strategii obcego. Jej szkicową definicję można znaleźć w artykule Stanisława Jaworskiego - po zamienieniu „Polski” na „Francję" pozostaje ona tu nader adekwatna: "„Strategia obcego « oznacza spojrzenie na Polskę oczyma kogoś z zewnątrz, pragnącego ją poznać, zbudować w sobie jakąś wiedzę" [S. Jaworski, Strategia obcego w prozie lat dwudziestych, w: tenże, Zakręty i przełomy. Studia o literaturze XX wieku, Kraków 2003, s. 10].
} 
toda $\mathrm{w}$ ich ujęciu. Polega ona - generalnie rzecz ujmując - na odkrywaniu kolejnych aspektów udawania i nieautentyczności, które stają się udziałem osób na hipodromie.

Tego rodzaju postawy Caillois określa mianem mimikry (mimicry). Gra i zabawa polega tu na tym, iż:

człowiek sam staje się postacią wyimaginowaną i zachowuje się stosownie do tego. Stajemy wówczas wobec serii różnorodnych poczynań, których wspólny charakter sprowadza się do faktu, że jednostka udaje, iż wierzy, jakoby była kimś innym, pozwala sobie to wmówić lub usiłuje wmówić otoczeniu. Zapomina o własnej osobowości, wyzbywa się jej, maskuje ją, by udawać coś innego. [...] Dodatkowym elementem tej grupy gier i zabaw jest więc naśladowanie i przebieranie się. [...] Przyjemność polega na tym, że jest się kimś innym lub uchodzi się za kogoś innego [G, s. 27-29].

Sienkiewicz rozpoczyna swoje obserwacje od dość beztroskiego etapu mimikry, który polega na aranżacji odpowiedniego stroju. Celem tej procedury nie jest uzyskanie personalnego incognito, ale - przeciwnie - wyróżnienie się wśród licznie zebranych uczestników. Tym zatem, na co pisarz zwraca uwagę $\mathrm{w}$ pierwszej kolejności, są narodowe ubiory gości przybyłych z odległych części świata. Ich enumeracja [por. s. 99-100] poprzedzona zostaje generalnym spostrzeżeniem, zgodnie $\mathrm{z}$ którym egzotyka ubiorów sprawia wrażenie „wielkiej jakiejś maskarady pod gołym niebem” [s. 99]. Analogiczna sytuacja pojawia się w przypadku elegantek $\mathrm{z}$ wyższych sfer, których wizyta na hipodromie związana jest $\mathrm{z}$ kreowaniem nowych trendów w kobiecej modzie [por. s. 100]. W obu przypadkach funkcjonuje identyczny mechanizm: bycie innym - obcym czy elitarnym - nie jest stanem oczywistym, ale wymaga nieustannego (i wyraźnego) manifestowania przy pomocy zaplanowanej „ekspresji westymenarnej”, dzięki której uczestnictwo w tak masowej imprezie jak wyścigi nie zniweluje owej odmienności.

Dalszy fragment korespondencji pokazuje, jak płynna jest granica między "byciem innym” a „udawaniem innego". Związek ten musiał Sienkiewicza intrygować, gdyż ilustrując jego działanie, odwołuje się do takich samych przykładów, jak poprzednio. W roli obcych występują teraz dalekowschodni dyplomaci ${ }^{6}$, których dwie delegacje zostają efektownie skontrastowane:

6 Widok tych obcych delegacji państwowych - łącznie z szachem perskim Naserem ad-Dinem - jest tu dla felietonisty oczywistością. Podkreślić należy, że ta postawa była uzasadniona nie tylko wystawą powszechną. W drugiej połowie XIX wieku dwa największe hipodromy: „Auteuil lub Longchamp (zależnie od kalendarza) są razem z Operą protokolarnym miejscem spotkań władców i zagranicznych szefów państw w trakcie oficjalnej wizyty w Paryżu" [G. Thibault, Un siecle de galop 1900-2000, Paris 2001, s. 9]. 
Oto ciągnie jakiś powóz zaprzęgnięty czterema końmi, a w nim Chińczycy. To Tiu-Tuu-Ling, wielki ambasador kwiecistego państwa, ze świtą. W następnym pan Maeda, pełnomocnik japoński ze swymi sekretarzami, poubierani już po europejsku, w cylindrach, z różyczkami w dziurkach od surdutów. Chińczycy na widok dobiegających na wyścigach koni krzyczą jeszcze: „O-hi! Jam-jam! O-hi!” - Japończycy już po europejsku: „Hourrah!” [s. 100-101].

Sienkiewicz o tym nie wspomina, ale komiczny aspekt tej scenki polega na tym, iż właściwa Japończykom fizjonomia zawsze pozostanie w dysharmonii z ich wysiłkami stylizowania się na europejską elitę. $W$ zestawieniu z Chińczykami Japończycy natychmiast objawiają więc zamiar naśladowczego upodobnienia, któremu sfera somatyczna - w przeciwieństwie do kulturowej - stawia ewidentny opór.

Podobny proces korespondent zauważa w gronie francuskiego establishmentu. Oto w jaki sposób sportretowany został Albert de Broglie - arystokrata i konserwatywny polityk, który do listopada 1877 r. sprawował urząd wicepremiera.

Ten np. dżentelmen - pisze Sienkiewicz - w towarzystwie dwóch innych, podstarzały mocno, a pragnący widocznie uchodzić za młodszego, niż jest, to ni mniej, ni więcej, tylko książę de Broglie, ów przyjaciel „moralnego porządku", który dla tego porządku pragnął wymieść ulice Paryża... kartaczami. Wymiatanie jest przecie koniecznym warunkiem porządku, na nieszczęście jednak dla pana Broglie, przy republikańskich pojęciach o porządku on sam stał się czymś kwalifikującym się do wymiecenia. Pozostaje mu teraz [...] nadrabiać miną. Ale to [...] niezbyt mu się udaje; cera też tego starego intryganta pożółkła, faworyty zbielały, a z twarzy znikły ślady owej dawnej energii, pychy i zaciętości pomieszanej z chytrą inteligencją. Starzec ów, którego widziałem śpieszącego na wyścigi, wozi swój własny grób w sobie. Jako polityk umarł już - i co więcej: ziemia mu cięży i pamięć ludzka cięży. Tak przechodzi chwała świata. Wypomadował się, wyróżował, wyszczotkował: jedzie oto na Longchamps [s. 101].

Jest wysoce nieoczywiste, dlaczego Sienkiewicz odsyła tu do wydarzeń sprzed ponad siedmiu miesięcy. Niefortunnie prowadzona przez rojalistów (tzw. stronnictwo „moralnego porządku”) kampania wyborcza i towarzyszące jej działania (m.in. zamykanie ulicznych lokali restauracyjnych) doprowadziła wówczas do klęski i upadku rządu de Brogile’a7 ${ }^{7}$ Pisarz jakby zamierzał dokonać kumulacji wszystkich niepowodzeń byłego wicepremiera: politycznych, moralnych i osobistych, związanych z nadchodzącą starością (w 1878 r. książę miał 57 lat). Wiele wskazuje na to, że to właśnie ostatnia

7 Zob. M. Sobolewski, Od drugiego cesarstwa do piątej republiki. Z dziejów politycznych Francji 1870-1958, Warszawa 1963, s. 61-63. 
kwestia jest tu zasadnicza ${ }^{8}$, a dwie pierwsze stanowią zarówno jej konsekwencję, jak i ewidentną manifestację.

Wprawne oko felietonisty natychmiast też zauważa, że to o starości chce zapomnieć udający się na hipodrom książę. Zabawa w „udawanie młodszego" - w domyśle: atrakcyjniejszego, a może i popularniejszego, wartościowszego - wymaga stroju, makijażu a nawet odpowiednich towarzyszy wyprawy. Znowu jednak sukces mimikry okazuje się problematyczny: mimo starannego doboru środków ciało buntuje się przeciw tym zabiegom i demonstruje swą prawdę. Sienkiewicz posuwa się wręcz do insynuacji, zgodnie z którą - niemożliwa do zamaskowania - starcza fizjonomia księcia bezlitośnie odzwierciedla procesy osobowościowe (tzn. zanik dawnych cech charakteru). Kontrast między zamiarem imitacyjnym a jego niezamierzonymi efektami nabiera zatem znamion groteskowej wizji.

Nie uszedł też uwagi Sienkiewicza autokreacyjny wysiłek ówczesnej gwiazdy teatru:

Rozczarowanie pociesza jednak widok Sary Bernardt. Osjaniczna dziewica, ubrana biało i spoczywająca na białych poduszkach powozu wśród koronek tiulowych mgieł i gazy, wygląda jakby jechała na chmurze. - „Biały kolor zwycięża! Biały będzie modny!" - szepcą kobiety. Inne twierdzą, że to tylko genre Sary Bernardt. Wielka artystka rzuca tymczasem omdlałe spojrzenia, jak gdyby miała umrzeć. Ale to także genre tylko, nic więcej [s. 104].

Precyzja pisarza staje się niemal naukowa: oto prezentacja aktorki zostaje podporządkowana terminowi, który znakomicie łączy aspekt pokazowej aranżacji (genre to styl bycia, sposób zachowania się, moda) z procedurą nawykową, powtarzalną (genre to także maniera). Aktorstwo, jak podkreśla Caillois [por. G, s. 29], jest aktywnością, która w zupełności oparta jest na mechanizmie mimikry; okazuje się jednak, że tzw. życie prywatne artystki teatralnej również nie stroni od tego typu efektów. Zabawa $\mathrm{w}$ „udawanie trupa", której oddaje się piękna kobieta, musiała być dla Sienkiewicza

8 Dwa lata wcześniej - w 1876 r. - w Paryżu ukazał się piętnasty tom wielkiego (i popularnego) słownika, który wydawał Pierre Larousse. Dzięki temu świadectwu można sobie wyobrazić, jakim problemem dla ówczesnych elit była kwestia starości. Autor pisał: „W epokach najwyższej cywilizacji - takiej jak nasza - gdzie nie ma mowy o innych radościach niż materialne, nieudolność starości pod tym względem sprawia, że ludzie z wielkiego świata odczuwają niewiarygodny lęk. Tymczasem nieudolność starości wynikająca z tego, czym jest przesycona, cierpi mniej z powodów mankamentów fizycznych, którymi jest skrępowana, niż z powodu pustki, jaką odczuwa w sobie; nudy, która jest owocem oczekiwania bliskiej śmierci. Wyczerpanie wyobraźni, a w konsekwencji nadziei, która jest owocem wyobraźni, często czyni starość ponurą, chociaż nie odczuwa ona cierpień rzeczywistych" [P. Larousse, Grand Dictionnaire universel du XIXe siècle, t. 15, Paris 1876, s. 1013]. 
zjawiskiem szczególnie interesującym ze względu na jego własny genre (tu w kolejnym znaczeniu: gustu, smaku) ${ }^{9}$. W odróżnieniu zaś od poprzednich przykładów wyraźny jest ów brak dysharmonii: zawodowa aktorka potrafi tak kształtować swoje ciało, aby jego ekspresja nie wymknęła się spod naśladowczych intencji.

Mimikra aktorska, której urokowi pisarz nie może się oprzeć, jest również zapowiedzią kolejnego zjawiska: oto $\mathrm{w}$ dalszych obserwacjach zwiększa się rola pierwiastka subiektywnego. Mechanizm ten jest tym bardziej wyraźny, że jego funkcjonowanie odbywa się w zakresie tego, co już - na początku - zostało zauważone, a czego powtórzenie stwarza rodzaj kompozycyjnej klamry. Znowu bowiem wychwycone zostają manifestacje inności tyle że teraz nie jest oczywisty ich intencjonalny charakter.

Paryskie elegantki z wyższych sfer pokazują się w znanych i „opatrzonych" kreacjach. Pisarz nie pominie więc złośliwych komentarzy w rodzaju: "Czyżby na koniec damy wielkiego świata postanowiły być skromniejsze od kobiet półświata?" [s. 102]. Sienkiewiczowi nieobca musiała być zatem spekulacja dotycząca strategii negatywnej, zgodnie z którą efekt wyróżnienia można uzyskać za pomocą swoistej niedbałości, braku wytworności. Szybko też zauważa klęskę takiego projektu: oto znana aktorka Anna Judic olśniła wszystkich swym strojem, który jest połączeniem mody retro ubrana jest „"w suknię robioną krojem z czasów Dyrektoriatu” [s. 102] - z najnowszymi trendami. Trudno jednak oprzeć się wrażeniu, że tym, co czyni ją wyjątkową, jest jej naturalna uroda, której kontemplacji Sienkiewicz nie potrafi się oprzeć.

Może też dzięki temu staje się coraz bardziej świadomy swoich preferencji. Słuchając listy arystokratycznych nazwisk referowanych przez przewodnika, pisarz generuje fantazmatyczny obraz [por. s. 102-103] wypraw krzyżowych, w których bierze udział kwiat francuskiego rycerstwa. I niemal natychmiast zauważa, że: „złudzenie krótko trwa” [s. 103]; historyczna transformacja tworząca wyjątkowych "feodałów" okazuje się więc bezpodstawna, a nawet - fałszywa. Nowoczesna arystokracja nie tylko bowiem niczym się nie wyróżnia, ale nawet - jak krytycznie podsumowuje pisarz - jest klasą znaczenie gorszą od tych, które aktualnie przewodzą francuskiemu społeczeństwu.

9 Zob. R. Koziołek, Ciała Sienkiewicza. Studia o płci i przemocy, Katowice 2009, s. 168 i n. Warto też oddać, że już we wcześniejszej korespondencji z Paryża, Sienkiewicz pisze o Sarze Bernardt w kategoriach „żałobnego Erosa”, chociaż swoje zaangażowanie stara się ukryć, nadając dyskursowi ironiczny charakter. Jak się bowiem okazuje, słynna aktorka: „sypia w pokoju obitym czarnym kirem, za łoże jej służy trumna, czeka śmierci, umiera i czekając na śmierć, kocha się" [s. 52]. 
Można przypuścić, iż nie bez powodu Sienkiewicz przechodzi od dawnej do nowoczesnej - mieszczańskiej - elity, którą definiuje jako: „innego rodzaju arystokracja" [s. 103]. Ta nazwa wydaje się znacząca: oto bowiem kryje się pod nią postać znanego pisarza (Wiktoryna Sardou) oraz wydawcy "New York Herald" (Gordona Benneta). Ich prezentacja - prima facie - nie zawiera nic szczególnego [por. s. 103-104], ale jeśli uwzględni się zastosowaną nomenklaturę, można zauważyć, że ludzie ci, mimo profesjonalnych sukcesów - czy też: z ich powodu - przejmują wiele nawyków dawnej arystokracji. W zdziwieniu, jakie ogarnia Sienkiewicza na widok eleganckiego pojazdu literata czy z powodu beztroskiej (tj. nieuzasadnionej zawodowo) wizyty „króla dziennikarskiego", kryje się więc sugestia o naśladownictwie stylu, który pierwotnie nie przynależy do tej warstwy.

$\mathrm{Na}$ tym, jak się wydaje, kończą się obserwacje dotyczące rozmaitych postaci na hipodromie. Wprawdzie Sienkiewicz kompletuje tu jeszcze listę najwyższych notabli [por. s. 104-105], ale funkcja tej enumeracji jest dekoracyjna; pozwala też uzasadnić przekonanie, że do Longchamps przyjechali absolutnie wszyscy.

Lista zachowań typu mimicry jest $\mathrm{w}$ tej korespondencji na tyle długa, że można wskazać na ich zróżnicowanie. Wspomniana już kompozycja klamrowa grupuje te fenomeny w sekwencję: bycie innym (obcy, elegantki) - udawanie innego (japońscy dyplomaci, były premier, aktorka) - bycie innym (elegantki, arystokraci, mieszczanie). Pierwiastek sztuczności i udawania osiąga swoje apogeum w członie środkowym, który można - za Caillois - określić mianem ludus. Sens pojęcia jest zbliżony do polskiej "gry", w której obowiązują określone reguły oraz -

mnożenie przeszkód, które coraz bardziej utrudniają osiągnięcie pożądanego celu. Cel ten nadal nie ma charakteru utylitarnego, aczkolwiek wymaga coraz więcej wysiłku, cierpliwości, zręczności, pomysłowości [G, s. 22].

Ludus jest jednak tworem późnym, wykształconym na bazie tendencji do szukania zadowolenia i radości; odpowiada mu polska "zabawa”, definiowana przez Caillois jako paidia. Są to postawy, którymi kieruje:

zasada rozrywki, rozpasania, swobodnej improwizacji i beztroski; przejawia się przez nie swoista, nieskrępowana, bujna wyobraźnia [...] [i] [...] spontaniczne przejawy instynktu zabawowego [...]. Dochodzi ona do głosu we wszelkiej uciesze $[\ldots][G$, s. 22, s. 34].

W obrębie mimicry pisarz zdecydowanie faworyzuje ten pierwiastek. Zgromadzeni na hipodromie paryżanie przede wszystkim bawią się - i dlatego wkładają takie a nie inne stroje czy podróżują wystawnymi powozami. 
Sam Sienkiewicz zdaje się ulegać temu nastrojowi, pozwalając sobie - wraz $\mathrm{z}$ podniesieniem poziomu subiektywizmu narracji - na frywolne (i oparte na fantasmagorycznych transformacjach lub tylko insynuacjach) żarty $\mathrm{z}$ dawnych oraz obecnych elit Francji.

\section{Mimikra per procura}

Intrygujący jest fakt, że przy tak panoramicznym ujęciu hipodromu Sienkiewicz aż trzykrotnie podejmuje ten sam temat: kobiecej mody i obowiązujących w niej trendów ${ }^{10}$. Powracanie tego motywu wymusza zatem refleksję nad jego funkcją, która okazuje się złożona i niebagatelna.

Elegantki z wyższych sfer "rozstrzygają kwestię mody na sezon letni” [s. 100] i dlatego „wszyscy zaś gapią się na pojazdy, z których królowe mody wydają nieodwołalne edykta" [s. 100]. Pozostałe (i licznie zgromadzone) kobiety pilnie wpatrują się $\mathrm{w}$ te kreacje i starają się zgadnąć, której z nich przypadnie - obwieszczone powszechnym uznaniem - zwycięstwo. $\mathrm{W}$ takim przypadku następuje proces kopiowania i rozpowszechniania danego stroju.

Tak naszkicowane zjawisko należy do kategorii określanej przez Caillois jako imitacja (lub udział) per procura. Jest to typowe zjawisko społeczeństw demokratycznych:

Uczestnictwo per procura to zdegradowana, „rozwodniona” forma mimicry, jedyna, która może jeszcze prosperować w świecie zdominowanym przez sprzymierzone zasady zasługi i szczęścia. [...] Każdy chce być pierwszy: kodeks i sprawiedliwość przyznają mu to prawo. Równocześnie jednak każdy podejrzewa, iż żadną miarą pierwszym nie zostanie z tej prostej przyczyny, że może nim być tylko ktoś jeden. Tak więc ludzie wolą zwyciężać za pośrednictwem osoby podstawionej, co jest jedyną metodą, aby wszyscy tryumfowali równocześnie, a tryumfowali bez wysiłku i bez ryzyka klęski [G, s. 105].

Przejęcie, odtworzenie najbardziej eleganckiego (i zapewne - najbardziej kosztownego) ubioru jest identyfikacją powierzchowną, „zewnętrzną" - a mimo to mechanizm ten jest na tyle utrwalony, iż Sienkiewicz nie waha się zaliczyć go do jednej z podstawowych funkcji hipodromu [por. s. 100]. $\mathrm{W}$ ten bowiem sposób każda z kobiet może okazać się najmodniejszą, czyli uzyskać kompensację braku własnej indywidualności i gustu.

10 Kwestia nieformalnego pokazu mody, jaki odbywał się na paryskich hipodromach, nie uszła uwagi historyków podkreślających masową skalę tego zjawiska [zob. G. Thibault, Un siécle de galop 1900-2000, Paris 2001, s. 9; J.-P. Chevallier, Les courses de chevaux, Paris 2008, s. I-XVI]. 
Dodatkową atrakcją owego pokazu jest nieprzewidywalność jego wyniku. Pisarz wyraźnie podkreśla, że „modny świat” jest społecznie dość zróżnicowany: składają się na niego zarówno arystokratki, aktorki, jak i - utrzymanki. Gdyby zatem rozbudowaną prezentację zachwytów nad kreacją Anny Judic [por. s. 102] uznać za nieformalny werdykt, okazałoby się, że zwycięstwo przypadło popularnej piosenkarce i aktorce. Takie rozstrzygnięcie zmniejsza dystans między „królową mody" a jej „poddanymi”, dzięki czemu cały proceder nabiera charakteru egalitarnego i dostępnego każdemu, komu pozwala na to status majątkowy.

Trudno jest też oprzeć się wrażeniu, iż ów element niespodzianki Sienkiewicz wprowadza tu na zasadzie prefiguracji. Jest to przygotowanie dla kolejnego konkursu, w którym także wszystko może się zdarzyć, a i wygrać może każdy, kto tylko postawi na właściwego konia. I ten specyficzny - hazardowy - egalitaryzm ${ }^{11}$ nieodmiennie fascynuje pisarza: „wobec najwyższego majestatu i największej znakomitości wszystkie inne gasną i stają się równe, taką zaś największą znakomitością jest Insulaire, koń hrabiego Lagrange'a prawdziwy król dnia dzisiejszego [...]" [s. 104].

\section{Interludium: ilinx}

Kiedy zakończona zostaje prezentacja imitacyjnych aspektów zgromadzenia, Sienkiewicz niezwłocznie przechodzi do opisu praktyk hazardowych. Deskrypcja zostaje jednak przerwana - i to w ważnym momencie przejścia od konkretnych scen do informacji uogólniających. Wiele wskazuje na to, że pisarz celowo dokonał tu rozbicia, umieszczając jedno wydarzenie w charakterze nieoczekiwanej „wstawki”. Jej komiczny (i delimitacyjny) sens sugeruje dawną praktykę interludium. Przebieg wypadków jest bowiem następujący:

Raptem jednak gorączkę zakładową przerywa okrzyk:

- Vive Stanley!

- Vive Stanley! - powtarzają tłumy otaczające jakiegoś jegomościa o ciemnej, mauretańskiej cerze, ubranego w biały, angielski hełm z żaglowego płótna.

11 Caillois zauważył, że w nowoczesnych społeczeństwach utracie dziedzicznych przywilejów oraz wzrastającej rywalizacji rynkowej odpowiada silny wzrost roli hazardu: „Dlatego właśnie $\mathrm{w}$ miarę jak alea urodzenia traci swą odwieczną supremację, a konkurencja ujęta w normy zatacza coraz szersze kręgi, widzimy, jak obok niej rozwijają się i prosperują tysiące wtórnych mechanizmów, które mają uszczęśliwić nielicznych wybrańców - zdumionych i zachwyconych - nagrodą poza konkursem" [G, s. 100]. 
„Vive Stanley! Na ręce go! W górę!”. I po chwili, na setkach rąk podniesionych widać człowieka podrzucanego jak piłkę, który widocznie nie wie, czego od niego chcą, wierzga nogami, wali pięściami i klnie, na czym świat stoi, po... holendersku. Policja przychodzi wreszcie na ratunek nieznanemu Stanleyowi, ale dopiero pierwszy dzwonek na trybunie uśmierza zamieszanie [s. 105-106].

Ten wybuch niekontrolowanego entuzjazmu wśród tłumu dotyczył prawdopodobnie któregoś z jeźdźców. Zgotowana w ten sposób owacja miała zapewnić powodzenie lub też unaocznić, jak bardzo ów sukces jest pożądany. Niemniej, podkreślając barierę językową i brak porozumienia, pisarz sugeruje niemal automatyczny charakter tych działań, na które sam zainteresowany nie ma wpływu. Wszystko - łącznie z gwałtowanym początkiem i końcem sytuacji - przypomina tu jakąś maszynę z lunaparku, której celem jest szybkie przemieszanie ciała, wstrząsy i wywołany tym zawrót głowy.

Caillois ten rodzaj rozrywki określa mianem ilinx. Polega on:

na dążeniu do oszołomienia; mamy tu do czynienia z próbą chwilowego unicestwienia stabilności odbioru i narzucenia świadomości swoistego upojonego lęku. Niezależnie od typu ilinx idzie o to, aby uczestnik osiągnął swego rodzaju spazm, trans lub upojenie, wobec których rzeczywistość nagle traci swe prawa [G, s. 30].

Groteskowy charakter tej zabawy (paidia) wynika oczywiście stąd, iż dżokej nie może - i nie powinien - w niej uczestniczyć. Nie tylko dlatego, że hipodrom jest (tzn. zaraz będzie) dla niego miejscem wysiłku i rywalizacji; również z powodu negatywnych skutków, które mają wpływ na jego kondycję fizyczną (i - szanse wygranej).

\section{Alea}

Korespondencja pisarza wiernie - $\mathrm{i}$ bez hipokryzji - oddaje podstawowy mechanizm działania toru wyścigowego. W nowoczesnych społeczeństwach niemal każde zawody sportowe są przedmiotem otwartej gry hazardowej. Mówiąc zaś dokładniej: zakłady bookmacherskie należą do kategorii alea, czyli -

wszelkich gier polegających [...] na decyzji, która nie zależy od gracza i na którą nie ma on najmniejszego wpływu, tak iż chodzi tu nie o zwycięstwo nad przeciwnikiem, lecz nad losem. [...] Tutaj grający nie tylko nie usiłują wyeliminować niesprawiedliwości związanej z losem, ale właśnie kaprys losu stanowi istotę 
gry. Alea ujawnia, kogo los darzy swą łaską. Grający zachowuje tu całkowitą bierność, niczego się od niego nie oczekuje, zbędna jest zręczność, wysiłek mięśni czy mózgu. Czeka jedynie z nadzieją i trwogą na wyrok losu, ryzykując jakąś stawkę [G, s. 25].

Sienkiewicz wyraźnie podkreśla, że gracze na hipodromie są w uprzywilejowanej sytuacji: ich wybór jest zdeterminowany narodowym charakterem wystawionych do gonitwy koni. Niemal wszyscy - zapewne nie bez wzajemnej interakcji graczy i bookmacherów - stawiają na najbardziej utytułowanego konia francuskiego - Insulaire. Jedynym "obcym” jest tu koń angielski Thurio, którego dosiadał sławny już wówczas jeździec - Tom Cannon. Jeżeli jednak ktoś obstawia tego zawodnika, to wyłącznie Anglicy - i to „przez miłość własną narodową" [s. 106].

Już powyższa charakterystyka naprowadza na zasadniczą refleksję, która - jak się wydaje - nieustannie nurtuje tu pisarza. Jeśli hazard wyklucza jakiekolwiek zdolności gracza, to musi on jednak podjąć decyzję w oparciu o jakieś przesłanki. Ich funkcjonowanie na paryskim torze można by nazwać: królestwem irracjonalności. Sienkiewicz dokładnie zbiera wszystkie ewentualne motywy, które skłaniają do obstawienia Insulaire; zbiera i poddaje je ironicznej próbie. Nikt tu nie bierze pod uwagę rangi angielskiego dżokeja, a nawet niedawnej porażki Insulaire; wszyscy natomiast ulegają zbiorowej ekspresji nacjonalizmu lub - dla odmiany - naśladują postępowanie pięknych i wpływowych kobiet, którym - zgodnie z magią starego przysłowia wszystko musi sprzyjać [por. s. 107]. Absurdu dopełnia zaś fakt, że gracze mniejszościowej (i przeciwnej) opcji zachowują się dokładnie tak samo; z tą jedynie drobną różnicą, iż obok typowego nacjonalizmu, wykorzystuje się też "ukrytą sympatię dla jakiego Anglika" [s. 107].

Sienkiewicz znakomicie uchwycił metodę tego szaleństwa, która polega na niejawnym uwarunkowaniu decyzji gracza. Nie dokonuje on wyboru w oparciu o bezpośrednią ocenę szans poszczególnych zawodników, ale szuka dodatkowych (i odległych) bodźców motywacyjnych, którym w sposób tyleż nieuzasadniony, ile całkowity zawierza. Identyczną diagnozę proponuje Caillois. Stwierdza, iż postawa podmiotu w alea polega na tym, że liczy on: „na wszystko: na minimalną wskazówkę, jakieś odchylenie od normy, które natychmiast uważa za znak wieszczy lub zapowiedź, na każdą niezwykłość, jaka tylko wpadnie mu w oczy - na wszystko, tylko nie na siebie" [s. 26]. I tak dokładnie musi być, ponieważ zwycięstwo - na razie tylko o nim wspomina korespondent - również jest czymś nadzwyczajnym; czymś, co pozostaje w sprzeczności z racjonalnym porządkiem i jego konsekwencjami. Sienkiewicz pisze: „Zakłady ogólne dochodzą jednak milionów. Właściciel konia, 
który wygra, mógł być wczoraj bankrutem, dziś, jeśli los posłuży, będzie milionerem" [s. 106-107]. Sens tego stwierdzenia byłby jeszcze wyraźniejszy, gdyby rozszerzyć jego zakres na każdego, kto gra (do czego zresztą pisarz później nawiąże). Irracjonalna magia hazardu polega na tym, że każdy może dzięki niemu zmienić kondycję, „przeskoczyć” poziom aktualnej egzystencji i wznieść się wyżej; i niepotrzebne są do tego żadne koneksje, wysiłek czy urodzenie, wystarczy "usłużny los", którym hazard nieustannie nęci - i łudzi - swoich wiernych.

\section{Agon}

Ostatni rodzaj opisywanej przez Sienkiewicza gry to pojedynek sportowy - w terminologii Caillois - agon.

Cała grupa gier i zabaw ma charakter zawodów, to znaczy walki w warunkach sztucznie stworzonej równości szans, pozwalającej antagonistom zmierzyć się w sytuacji idealnej, dzięki której przewaga jest ściśle wymierna i niepodważalna. W każdym więc wypadku współzawodnictwa idzie o jakąś jedną cechę (szybkość, wytrwałość, siłę i pamięć, zręczność, pomysłowość), przejawiającą się w ściśle określonych granicach bez żadnej pomocy zewnętrznej, tak że zwycięzca jawi się jako najlepszy w danej kategorii wyczynowej [G, s. 23].

Autor dodaje jeszcze ważną cechę:

uprawianie agon zakłada napiętą uwagę, odpowiedni trening, maksymalny wysiłek i wolę walki, wymaga zdyscyplinowania i wytrwałości. Zawodnik jest tu zdany na własne możliwości, musi dać z siebie wszystko, na co go stać, równocześnie zaś postępować lojalnie przestrzegając przyjętych warunków; dzięki tej równości stworzonej przez warunki przewaga zwycięzcy nie podlega dyskusji [G, s. 24].

Relacja z przebiegu wyścigu oparta jest dokładnie na powyższych regułach. Pisarz podkreśla współzawodnictwo, dochodzące do ostatnich granic wyczerpanie koni, jak również - przestrzeganie zasad fair play i niepodważalny (chociaż niełatwy do uchwycenia) wynik zawodów.

Zarazem jednak wydarzenia te zostały poddane zabiegom teatralizacji. Dotyczy to zarówno tego, co dzieje się na widowni, jak i sytuacji rozgrywającej się na torze. W pierwszym przypadku występuje gwałtowna zmiana: publiczność najpierw w ciszy i skupieniu kontempluje wyścig, a następnie daje upust emocjom za pomocą głosu (okrzyki) i gestu (oklaski).

Same zawody korespondent zrelacjonował konsekwentnie, wykorzystując fabularny schemat akcji. Pojawia się tu zatem: przed-akcja (bieg przed 
linię startu), zawiązanie (start i pierwsze okrążenie), rozwinięcie (drugie okrążenie), perypetia (trzecie okrążenie), punkt kulminacyjny (finisz) oraz po-akcja (ogłoszenie wyniku).

Trudno jest oprzeć się wrażeniu, że Sienkiewicz też bierze tu udział $\mathrm{w}$ - innych, rzecz jasna - zawodach. Jego tekst osiąga bowiem w tejże partii autentyczne mistrzostwo: lakoniczna narracja [por. s. 107-108] znakomicie syntetyzuje oba aspekty teatralizacji, oddaje ich wzrastającą dynamikę. Autor nie zapomina przy tym o wrażeniach wizualnych, jakich musi dostarczyć polskiemu odbiorcy.

\section{Po zawodach}

Nie jest oczywiste, w jaki sposób należy ująć komentarze Sienkiewicza dotyczące wyniku gonitwy i przegranej francuskiego faworyta. Zwracając uwagę na konieczność „spłacenia” przegranych sum, pisarz - na zasadzie a contrario - wskazuje na istotną cechę alea. Jak podkreśla Caillois:

los szczęścia to nie tylko jawna forma niesprawiedliwości, darmowego i niezasłużonego dobrodziejstwa; to także ośmieszenie pracy, cierpliwego i zaciekłego trudu, oszczędności, świadomego odmawiania sobie z myślą o przyszłości; jednym słowem to ośmieszenie wszystkich cnót potrzebnych $\mathrm{w}$ świecie skazanym na pomnażanie dóbr [G, s. 136; por. G, s. 101].

Francuska publiczność, która bez wahania postawiła olbrzymie kwoty na "faworyta", dała się zatem ponieść iluzji łatwego bogactwa, do którego nie dochodzi się dzięki wysiłkowi. Pewność co do owego „losu” okazała się pychą - antyczną hybris, której tłum bezwiednie, irracjonalnie uległ i za którą teraz musi ponieść karę. Niezależnie od stopnia uszczuplenia zasobów majątkowych - pisarz kładzie nacisk na „bankructwo” - każdy przegrany będzie musiał rozpocząć starania o ich odnowienie; starania, których najbardziej uprzywilejowaną formą pozostaje praca.

Przy takim złożeniu można spojrzeć na puentę felietonu w kategoriach innych niż moralne. Sienkiewicz istotnie jest przeciwko hazardowi - który rujnuje nawet wielkie fortuny - ale nie przeciw wyścigom. Postuluje zatem oderwanie agon od alea, tak aby - jak należy przypuszczać - wyścigi były "czystym" spektaklem, wyłącznie rozrywką, nie mającą nic wspólnego z pomnażaniem dóbr. A jeśli - to w zupełnie inny sposób: utrzymywanie odpowiedniej hodowli koni wpływa na poprawę całej rasy, która przecież nie na wyścigi, ale do pożytecznej pracy jest kierowana [por. s. 109]. 


\section{Wnioski}

Szukając rozrywki - i tematu do felietonu - w dziewiętnastowiecznym Paryżu można było wybierać między nieprzebranym wręcz zestawem kasyn, teatrów czy choćby lunaparków. A jednak Sienkiewicz zdecydował się na prezentację niedzielnych zawodów na hipodromie. Jeśli nie uczynił tego ze zwykłego snobizmu, można przypuścić, iż kierował się przekonaniem (czy raczej intuicją) o "poważnym” i zarazem fascynującym charakterze owego zjawiska. Mówiąc zaś dokładniej: to właśnie ten (a nie inny) rodzaj rozrywki pozwala na wnikliwe obserwacje dotyczące francuskiego społeczeństwa (tzn. społeczeństwa nowoczesnego par excellence), a jednocześnie dostarcza obfitego materiału związanego $\mathrm{z}$ funkcjonowaniem gier i zabaw. $\mathrm{W}$ tej właśnie kwestii Caillois stwierdza: „wyścigi konne, będące dla dżokejów typowym agon, są równocześnie widowiskiem, więc przynależą do mimicry, a także stanowią pretekst do zakładów, dzięki czemu współzawodnictwo prowadzi do alea" [G, s. 69]. Dodać tu jeszcze należy, iż wprowadzając - w ewidentnie sztuczny sposób - drobny epizod o charakterze ilinx, Sienkiewicz intuicyjnie dąży do stworzenia kompletnego katalogu tych zachowań. Jeśli tak, to nie jest możliwe, aby nie uwzględnił zasadniczego problemu, jaki stwarza niniejsza lista: problemu wzajemnych relacji między jej poszczególnymi elementami.

Zagadnienie to Caillois określa mianem rozszerzonej teorii gier i zabaw, która poszczególne rodzaje łączy w związki binarne. Relacje mogą być przygodne, ale kluczowe są te, $\mathrm{w}$ których dochodzi do istotnej zależności. Badacz wskazuje na dwie takie pary: mimicry-ilinx oraz agon-alea. Pierwsza więź jest charakterystyczna na społeczeństw pierwotnych, gdzie funkcjonuje ona w ramach porządku religijnego [por. G, s. 72]. Złamanie dominacji owego mechanizmu Caillois uważa za podstawową przyczynę, dzięki której doszło do powstania tego, co określa mianem nowoczesności. Wyrzeczenie się: „czarów mimicry oraz ilinx przypomina przejście przez bardzo ciasną bramę, która jednak wiedzie ku cywilizacji i ku historii (ku postępowi, ku przyszłości) [...]" [G, s. 122, por. G, s. 88]. Zmiana została dokonana, zatem - w konsekwencji - mimicry i ilinx: „Obecnie występują [...] tylko i jedynie z osobna, zubożałe i wyizolowane w świecie, który je odrzuca i który zresztą prosperuje tylko o tyle, o ile potrafi je poskromić lub oszukać ich gwałtowność" [G, s. 113].

Felieton Sienkiewicza potwierdza tak postawioną tezę. Mimicry i ilinx mimo iż pozostają na wspólnym poziomie paidia - nie łączą tu żadne więzi. „Pokazów mody”, „teatru życia codziennego" czy spontanicznego podrzucania nikt nie wiąże z ekstatyczną transformacją osobowości. Tym natomiast, co interesuje pisarza, są konsekwencje owego rozpadu. Okazuje się bowiem, iż cały proces składa się jakby z dwóch faz: w pierwszej (jak diagnozuje 
Caillois) następuje uproszczenie i separacja, ale w drugiej - pojawia się wzbogacenie i rekonstrukcja więzi.

Zjawisko to jest widoczne na przykładzie mimicry ${ }^{12}$, która nie jest $\mathrm{w}$ stanie funkcjonować w próżni i niemal natychmiast zaczyna grawitować w kierunku trwałego i kluczowego związku alea-agon. Dochodzi przede wszystkim do fuzji między mimicry i agon: wszystko, co w wyścigach ma charakter widowiska - podział na oglądających i oglądanych, mimicry per procura, dramatyzacja przebiegu, perypetia - posiada identyczną strukturę i zaczerpnięte zostało z obserwacji dotyczących teatralnych zachowań publiczności. Ta kontaminacja nadaje samej rywalizacji sportowej większą ekspresję: czyni z niej zjawisko interakcyjne, zespołowe i zarazem estetyczne; tej wyrazistości brakuje samej mimicry, którą można oglądać na hipodromie.

Tym, co w felietonie Sienkiewicza pozostaje najbardziej frapujące, jest związek, jaki pojawia się między mimicry i alea. Takie połączenie Caillois uważał za niemożliwe:

Gracz oczekuje wyroku zapewniającego o bezwarunkowej łasce losu. W chwili gdy o to zabiega, nie może naśladować kogoś innego, ani też podawać się za kogoś innego. [...] W przeciwnym razie wkraczamy $\mathrm{w}$ dziedzinę magii: idzie o przełamanie losu. Zasada alea [...] ulega zniweczeniu i nie może być mowy o grze czy zabawie w ścisłym sensie tego słowa [G, s. 70].

Pisarz dopuszcza wprawdzie, że typowanie na wyścigach może być kwestią ",czystego kaprysu” [s. 107], niemniej jest też oczywiste, że sytuacje takie uznaje za marginalne. Zasadniczy mechanizm polega na powszechnym kopiowaniu: obstawia się tak, jak obstawiają inni - prawdziwi Francuzi (lub Anglicy) lub piękne francuskie kobiety (lub angielscy mężczyźni). Zachowania ludzkiej zbiorowości są nieuchronnie naznaczone piętnem naśladownictwa, które - analogicznie od tego, co dzieje się na torze - spaja i nadaje dynamizm każdej z grup.

Caillois ma rację, twierdząc, że zbliżenie mimicry i alea niweluje grę. W tej magii ${ }^{13}$ istotnie najważniejsze jest „przełamanie losu”, a los - „to opór

12 Trzeba doprecyzować: tylko na przykładzie mimicry. Ilinx bowiem jest tu i spłycone, i zawieszone w kompletnej próżni. Jest niewątpliwe, iż taki właśnie zamysł kierował pisarzem, skoro w zakończeniu nie przedstawił radości czy wręcz oszołomienia tych, którzy na angielskiego konia postawili (o przygodnym związku alea i ilinx zob. G, s. 70-71).

13 Wiele wskazuje więc na to, że $\mathrm{w}$ tym momencie nowoczesna teoria gier traci swą moc eksplikacyjną. Wydaje się bowiem, iż Sienkiewicz bliższy jest tu tzw. teorii przeżytków, którą sformułowała XIX-wieczna antropologia. Akurat w okresie od 1876 do 1878 ukazał się w Paryżu francuski przekład Cywilizacji pierwotnej E. B. Tylora (wyd. org. 1871). Brytyjski antropolog nie ma wątpliwości, iż wszelkiego rodzaju gry hazardowe są pozostałością właśnie po magicz- 
stawiany przez naturę, przez świat zewnętrzny albo przez wolę bogów sile, zręczności i wiedzy człowieka" [G, s. 72].

Oto zatem wyścigi stają się okazją do aktu kompensacji na niemal narodową skalę: zwycięstwo - dzięki powszechnie zyskanym fortunom - pokazałoby, że zespolona zbiorowość jest w stanie zapanować nad własnym przeznaczeniem czy nawet niepowodzeniem. Sienkiewicz znakomicie jednak pokazuje "cenę", jaką trzeba zapłacić za tego rodzaju magiczne środki. Z siedmiu startujących koni tylko jeden jest obcy, angielski. Jeśli więc wygrać "musi" każdy, tylko nie ten, to oczekiwania te są w istocie oparte na zakamuflowanym mechanizmie wykluczenia. Zanim jeszcze bieg się rozpocznie, jedyna Francuzka (panna Berta Legrand), która odważyła się postawić na konia angielskiego, już podlega - na razie ujętemu w formie żartu ${ }^{14}$ - ostracyzmowi [por. s. 107].

Doganiający Insulaire Thurio nie bez powodu nazwany zostaje "piekielnym Anglikiem” [s. 108]. To właśnie ten koń staje się symbolem „złego losu”, jaki prześladuje Francuzów - i którego trzeba się w zbiorowy i widowiskowy sposób pozbyć. Ten proceder swoim irracjonalizmem, wręcz magią, wyraźnie niepokoi Sienkiewicza, a im bliżej do puenty felietonu, tym bardziej niepokój ten zdaje się narastać. Z tego, jak sądzę, powodu pojawia się postulat separacji agon i alea ${ }^{15}$; separacji, do której przegrana "faworyta" może zachęcać, a która w każdym razie nie zostanie negatywnie odebrana. Jeśli wyścigi pozostaną tylko wyścigami, wówczas przestaną kreować tego rodzaju iluzje, a nawet okażą się instytucją przydatną w obrębie porządku pracy i - last but not least - zysku.

nej sztuce przepowiadania losu. Okazuje się, iż - niegdyś - człowiek prymitywny „skłonny jest przypuszczać, że istoty nadprzyrodzone kierują ręką wróżbity albo gracza, mieszają losy i odwracają kości, aby okazać swoją wolę" [E. B. Tylor, Cywilizacja pierwotna, przeł. Z. A. Kowerska, t. 1, Warszawa 1896, s. 77]. Sugestię taką potwierdza klamrowe usytuowanie - przed i po wyścigu - wypowiedzi szacha Nasera: „Allach jeden wie!” i „Allach wielki” [s. 107 i 108]. Nota bene: w swej pracy Tylor powołuje się na angielską publikację, w której autor „bronił gier hazardowych dla rozrywki, ale nie o pieniądze" [tamże, s. 78].

14 Sienkiewicz rozpisuje imię własne konia (Thurio) na zdanie: „śmiejesz się wysoko”, które stanowi oczywisty przykład „żartobliwej gry onomastycznej” [E. Jędrzejko, Strategia tekstotwórcza a gry językowe w literackich nazwach własnych, w: Gry w języku, literaturze i kulturze, red. E. Jędrzejko, U. Żydek-Bednarczuk, Warszawa 1997, s. 71], ale w kontekście damy z wyższych sfer ma raczej pejoratywny podtekst.

15 Caillois znakomicie dostrzega, że w związku alea-agon, pierwszy człon jest destrukcyjny, a drugi - aktywny i twórczy. Sam zatem także formułuje diagnozę, która dostrzega potrzebę wyeliminowania alea: „W społeczeństwach rządzonych przez związek zasług i przypadku występuje również stały wysiłek (realizowany ze zmiennym szczęściem i zmiennym tempem), by zmniejszyć udział przypadku na rzecz sprawiedliwości. Wysiłek ten nosi miano postępu" [G, s. 74]. 


\section{Modern Homo Ludens. \\ Parisian Hippodrome in Henryk Sienkiewicz's Correspondence \\ Summary}

The article analyzes the column written by Henryk Sienkiewcz which concerns betting on horse races in Paris in 1878. Roger Caillois' categories such as mimicry, alea, ilinx and agon, prove that horse racing contains all aspects of modern gambling, which turns it into a relict of dangerous, magical thinking.

Keywords: Henryk Sienkiewicz, horse races, play in literature 